\title{
PREDICTION OF DISTANT EDUCATIONAL GOALS BY GOALS IN OTHER DOMAINS AND PERCEIVED CONTEXTUAL OPPORTUNITIES
}

\author{
Aleksandrs Kolesovs \\ University of Latvia, Latvia
}

\begin{abstract}
Lifelong learning is linked to successful economic participation. At the same time, individual activities are framed by contextual opportunities for education and occupation. This study explored personal and contextual factors predicting choice of education as a distant goal among emerging adults. Research participants were 120 emerging adults aged from 20 to 30 living in Riga (62\% females). The participants evaluated to what extent their near and distant goals associate with different life domains and reported perceived opportunities for fulfillment of these goals provided by their living place. Distant goals in the educational domain were positively predicted by current educational, distant occupational, and self-related goals and negatively predicted by higher perceived opportunities provided by their living place. The last finding indicates an association of a perceived lack of opportunities in the local context with a need for planning the further education.
\end{abstract}

Keywords: contextual opportunities, education, emerging adults, personal goals.

\section{Introduction}

Transforming societies challenge individual values, goals, plans, and action patterns (Pinquart \& Silbereisen, 2004). Psychological (Arnett, 2004; Nurmi, 2004) and educational (Appleby \& Bathmaker, 2006) researchers confirm that education is one of significant resources for coping with these challenges. Conceptions of lifelong learning reflect increasing individual need for planning continuous education in a combination with society's request for knowledge economy (e.g., Brine, 2006). In addition, prospective views of educational activities are related to a context in which these activities are planned to occur (Sandford, 2013). The aim of this study was to specify personal and contextual factors predicting subjective importance of education as a distant goal.

In the field of psychology, comparisons of adolescents' goals in different countries (e.g., Nurmi et al., 1995; Chang et al., 2006) demonstrate that educational, occupational, and family domains are the main themes among their views of the future. Aimed at preparing for a career, studying remains among the main activities for emerging adults till 30 (Arnett, 2004). During the preparation, individuals are choosing, continuing, or changing educational trajectories looking for a more effective entry into the field of economic production (Nurmi, 2004). Students' involvement in educational activities is regulated by internal and external motives (Vansteenkiste et al., 2006) and by near and long-term consequences of their action (Kauffman \& Husman, 2004). 
Educational researchers also emphasize a crucial role of education in preparing for the future or even "futures" reflecting various possibilities and uncertainty associated with socioeconomic changes (Sandford, 2013). Importance of education for the further occupational activities leads to increasing role of lifelong learning (Appleby \& Bathmaker, 2006; Brine, 2006) as continuous training and development promoting successful economic participation (Hughes et al., 2006).

Researchers from both fields (e.g., Nurmi, 2004; Sandford, 2013) agree that socioeconomic and cultural contexts channel individual choices by providing opportunities or constraints for their education and employment. For example, community studies (Arcidiacono et al., 2007) demonstrated that perceived low opportunities at a living place lead to a sense of powerlessness in young people. Coping with powerlessness differed among individuals. Many of them were not engaged in social activities and future planning. At the same time, some of youths were oriented to social participation and achievement.

These findings reveal variation in individual reactions to similar contextual conditions and confirm importance of individual-context interaction for understanding future plans in general (Nurmi, 2004) and in the educational domain in particular (Sandford, 2013). Individuals need balancing their interests and priorities with opportunities and possible consequences of their choices (Nurmi, 2004). Therefore, it is important to take into account multiple factors at individual and contextual level in order to predict distant educational plans.

Previous studies demonstrated relations between personal goals and demographic factors, cultural context, socioeconomic situation, and parents' support (for a review see Nurmi, 1991; Seginer, 2009). In order to specify factors predicting distant educational goals, the present study tests a regression model with demographic factors, importance of current educational goals and of near and distant goals in other domains, perceived support, and perceived opportunities at a living place as independent variables and importance of distant goals in the domain of education as a dependent one.

\section{Method}

Participants. Research participants were 120 emerging adults aged from 20 to 30 living in Riga (mean age $=22.9, S D=2.9$ ). The most part of participants were students $(92 \%)$, some of them have completed some level of higher education (31\% of the sample). Among participants, $62 \%$ were females, $58 \%$ working, and just $9 \%$ married. The number of participants was in accordance with an expected ratio of cases to independent variables in order to evaluate individual predictors in a multiple regression model (Tabachnick \& Fidell, 2007).

Measures. A new measure of personal goals and perceived context was developed on a basis of previous studies demonstrating relatively stable structure of the main domains across cultures (Chang et al., 2006; Kolesovs, 
2013; Nurmi et al., 1995; Seginer, 2009). A seven-point Likert-type scale was used for answering questions regarding personal goals, perceived support, and opportunities.

Importance of personal goals was evaluated by answering two questions: "To what extent your near (distant) goals are associated with the following domains?" For both near goals and distant goals, a list of domains included education, occupation, family, children, parents and relatives, friends, and personal growth. Importance of each domain was assessed from 0 ('not topical') and 1 ('minimal extent') to 6 ('maximal extent').

The near and distant goals related to a family and children formed a Family goals sub-scale (internal consistency assessed by Cronbach's alpha coefficient was .81). Goals related to parents, relatives, and friends constituted a Network goals sub-scale (Cronbach's alpha $=.84$ ). Near and distant goals regarding personal growth were joined into a Self-related goals sub-scale (Cronbach's alpha $=.70$ ). For each sub-scale the sum of answers was divided by a number of items in the sub-scale. Near and distant goals in the domain of education or occupation were assessed at a single item level taking into account research objectives.

Perceived support at a meso-system level was evaluated as support for goal attainment provided by parents, siblings, relatives, and friends by asking "To what extent your goals are supported by people listed below?" ( $0=$ 'not topical'; $1=$ 'minimal support'; 6 = 'maximal support'). Cronbach's alpha coefficient for the sub-scale was .70. Support from a romantic partner or spouse was assessed at a single item level.

Opportunities provided by a living place were evaluated answering the question "Does your living place provide opportunities for fulfillment of your goals?" Two items (for near and distant goals respectively) were assessed in a scale from 1 ('minimum') to 7 ('maximum'). Cronbach's alfa coefficient for the sub-scale was .74.

Subjective income level was assessed by evaluating relative difficulty to cover monthly expenses. A 7-point scale included values form 1 ('very difficult') through 4 ('relatively easy') to 7 ('very easy'). Income range was assessed as monthly income per person. Six intervals were suggested taking into account an average income per person per month in a household (Central Statistical Bureau of Latvia, 2014).

Procedure. The research was conducted in fall 2014. The questionnaire was completed individually or in groups of students with no time limit and was administered in the Latvian language.

\section{Results}

A multiple hierarchical linear regression was applied in order to answer the research question. Table 1 demonstrates the results at each step of the analysis. 
The variance inflation factor varied from 1.17 to 1.99 indicating acceptable level of covariance among independent variables.

Table 1. Multiple hierarchical linear regression on distant educational goals $(N=120)$

\begin{tabular}{|c|c|c|c|}
\hline Predictors & B & SE B & $\boldsymbol{\beta}$ \\
\hline \multicolumn{4}{|c|}{$\begin{array}{l}\text { Step } 1 \\
\text { Model: } \mathrm{F}(6,113)=2.50, \mathrm{p}<.05 ; \mathrm{R} 2=.12 ; \text { adjusted } \mathrm{R} 2=.07\end{array}$} \\
\hline Age & 0.14 & 0.07 & $.27 *$ \\
\hline Gender & -0.99 & 0.30 & $-.30 * *$ \\
\hline Higher education & -1.05 & 0.41 & $-.30 *$ \\
\hline Marriage & 0.06 & 0.52 & .01 \\
\hline Income range & -0.03 & 0.13 & -.02 \\
\hline Perceived income & 0.15 & 0.14 & .11 \\
\hline \multicolumn{4}{|c|}{$\begin{array}{l}\text { Step } 2 \\
\text { Model: } \mathrm{F}(12,107)=8.04, \mathrm{p}<.001 ; \mathrm{R} 2=.47 ; \text { adjusted } \mathrm{R} 2=.42 ; \Delta \mathrm{R} 2=.35 \text {. }\end{array}$} \\
\hline Age & 0.07 & 0.05 & .13 \\
\hline Gender & -0.39 & 0.26 & -.12 \\
\hline Higher education & -0.50 & 0.34 & -.15 \\
\hline Marriage & -0.20 & 0.45 & -.04 \\
\hline Income range & -0.08 & 0.11 & -.06 \\
\hline Perceived income & 0.16 & 0.11 & .12 \\
\hline Near educational goals & 0.42 & 0.10 & $.34 * * *$ \\
\hline Near occupational goals & -0.14 & 0.12 & -.10 \\
\hline Distant occupational goals & 0.37 & 0.11 & $.29 * *$ \\
\hline Family goals & 0.06 & 0.10 & .06 \\
\hline Network goals & 0.02 & 0.10 & .01 \\
\hline Self-related goals & 0.39 & 0.13 & $.24 * *$ \\
\hline \multicolumn{4}{|c|}{$\begin{array}{l}\text { Step } 3 \\
\text { Model: } \mathrm{F}(15,104)=7.07, \mathrm{p}<.001 ; \mathrm{R} 2=.51 ; \text { adjusted } \mathrm{R} 2=.43 ; \Delta \mathrm{R} 2=.04\end{array}$} \\
\hline Age & 0.08 & 0.05 & .14 \\
\hline Gender & -0.49 & 0.26 & -.15 \\
\hline Higher education & -0.42 & 0.34 & -.12 \\
\hline Marriage & -0.36 & 0.45 & -.06 \\
\hline Income range & -0.14 & 0.11 & -.11 \\
\hline Perceived income & 0.22 & 0.11 & .15 \\
\hline Near educational goals & 0.40 & 0.10 & $.33 * * *$ \\
\hline Near occupational goals & -0.10 & 0.12 & -.07 \\
\hline Distant occupational goals & 0.37 & 0.11 & $.29 * *$ \\
\hline Family goals & 0.05 & 0.10 & .05 \\
\hline Network goals & 0.02 & 0.10 & .02 \\
\hline Self-related goals & 0.39 & 0.13 & $.24 * *$ \\
\hline Perceived support (meso-system) & -0.04 & 0.09 & -.04 \\
\hline Perceived support (partner relations) & 0.06 & 0.06 & .09 \\
\hline Perceived opportunities (living place) & -0.19 & 0.08 & $-.17 *$ \\
\hline
\end{tabular}

Notes. Female and male students were coded as 1 and 2, respectively. Higher education and marriage were coded as 1 (presence) and 0 (absence).

${ }^{* * *} p<.001$. $^{* *} p<.01$. $^{*} p<.05$. 
Step 1 involved gender (a nominal variable), higher education and family status (binary "dummy" variables indicating presence or absence of a characteristic), and participants' age, income range, and subjective income level as independent variables. Step 2 added to the model near goals in the domain of education, near and distant occupational goals, family goals, social network goals, and self-related goals. Step 3 included perceived support at a mesosystem level, perceived support from a romantic partner, and perceived opportunities for fulfillment of personal goals provided by a living place.

At Step 1, demographic factors provided relatively low contribution of three independent variables to prediction of distant educational goals. Age of emerging adults positively predicted their distant goals associated with education. At the same time, having a higher education negatively predicted importance of distant educational goals. Females associated their distant goals with education in a greater extent than males. The model at Step 1 explained only $12 \%$ of variance of the dependent variable

At Step 2, demographic factors lost their significance when personal goals were added to the model. Importance of near educational goals became the most significant predictor of distant educational goals. It was followed by importance of distant occupational goals and self-related goals. The model at this step explained $47 \%$ of variance of the dependent variable.

Finally, Step 3 added perceived opportunities provided by a living place as a negative predictor for setting distant educational goals. The model at this step explained $51 \%$ of variance. It should be noted that adding assessment of perceived contextual opportunities and support did not change significance of previously revealed predictors (near educational, distant occupational, and selfrelated goals).

\section{Discussion}

The results demonstrate that predictors of distant educational goals can be revealed at different levels. The most significant predictors are identified at the level of personal goals. In addition, perception of possibilities provided by participants' living place (local social context) is also among significant predictors of distant goals in the domain of education. These findings need to be discussed in greater detail.

The performed test of demographic variables revealed higher interest in continuing education among females and relatively lower interest in education among emerging adults having higher education. However, adding personal goals excludes any demographic variable from a list of predictors and indicates higher importance of subjective evaluation of future goals. Importance of educational goals in the near future and distant goals in the field of occupation predicted positively distant educational goals, while demographic variables lost their significance. Significance of near educational goals in prediction of 
continuing education confirms subjective importance of education among other personal goals for emerging adults (Arnett, 2004; Nurmi et al., 1995; Seginer, 2009) and a role of involvement into educational activities for higher academic motivation (Kauffman \& Husman, 2004). The second predictor is in accordance with a view of lifelong learning as aimed at successful economic participation emphasized by psychologists (Nurmi, 2004) and educational researchers (Hughes et al., 2006). In addition, both kinds of predictors of the further education confirm a view on students' motivation as determined by near (education) and distant (occupation) outcomes of their learning (Kauffman \& Husman, 2004).

It should be noted that a positive relationship between distant educational and distant occupational goals indicates instrumental value of education. At the same time, self-related goals as a predictor of educational goals demonstrate high potential of education for personal growth. Young people more interested in personal development assessed educational track as a more important possibility for their development. Therefore, long-term educational plans can be considered as a resource for actualization of personal growth and development as an intrinsic motive (Vansteenkiste et al., 2006).

The last, but not the least significant finding of this study is an opposite relationship between distant educational goals and perceived opportunities for fulfillment of personal goals provided by the living place. It means that a lower level of opportunities associated with the local social context predicts higher importance of distant educational goals. Therefore, higher effort in the educational domain can be considered as an adjustment strategy aimed at more effective preparation for the future under insufficient opportunities for individual development associated with the current socioeconomic environment (Nurmi, 2004). This finding is also in accordance with a view of education as a resource for adaptation to uncertainty associated with the future and changing socioeconomic conditions (Sandford, 2013).

An exploratory nature of the study leads to various limitations. The most important of them is a research sample including emerging adults selected higher education as a way for their socialization. As previous studies demonstrated (Arcidiacono et al., 2007), active participation and pursuit for personally and socially valuable goals is one of constructive ways among possible developmental trajectories. In addition, research participants were living in Riga (the capital of Latvia) providing relatively high number of alternatives at each level of education. Therefore, revealed tendencies can be generalized to a group of emerging adults living in a relatively favorable social context and oriented to a career based on higher education. The further research should involve participants living in different contextual conditions for a better understanding of their role in planning short- and long-term educational and career activities. 


\section{SOCIETY. INTEGRATION. EDUCATION. Volume IV}

Changing significance of predictors within a hierarchical regression analysis indicates a possibility to apply a mediation model aimed at revealing relationships among independent variables. Two aspects of the relationships can be tested: a) mediation of demographic variables by personal goals; b) interdependence of personal goals and possible mediation effects among them. Requiring more sophisticated statistical methods, this kind of analysis needs also a broader research sample.

\section{Conclusions}

It can be concluded that distant goals in the domain of education are positively related to consideration of educational goals in a near perspective, distant occupational goals, and individuals' orientation to personal growth. In addition, perceived lack of opportunities in the local context facilitates planning the further education. These findings emphasize significance of individuals' involvement into educational activities aimed at adapting to socioeconomic context and subjective value of a career and personal development. It opens a dual perspective on potential benefits of lifelong learning including instrumentality of acquired knowledge and personal growth associated with education.

\section{References}

Appleby, Y., \& Bathmaker, A. (2006). The new skills agenda: Increased lifelong learning or new sites of inequality? British Educational Research Journal, 32(5), 703-717.

Arcidiacono, C., Procentese, F., \& Di Napoli, I. (2007). Youth, community belonging, planning and power. Journal of Community \& Applied Social Psychology, 17, 280-295.

Arnett, J. J. (2004). Emerging adulthood: The winding road from the late teens through the twenties. Oxford: Oxford University Press.

Brine, J. (2006). Lifelong learning and the knowledge economy: Those that know and those that do not - the discourse of the European Union. British Educational Research Journal, 32(5), 649-665.

Central Statistical Bureau of Latvia (2014). Income and living conditions in Latvia, 2013. Collection of statistical data (14). Rīga: CSB of Latvia. Retrieved from http://www.csb.gov.lv/sites/default/files/nr_14_ienakumi_un_dzives_apstakli_latvija_2 013_14_00_lv_en.pdf

Chang, E. S., Chen, C., Greenberger, E., Dooley, D., \& Heckhausen, J. (2006). What do they want in life?: The life goals of a multi-ethnic, multi-generational sample of high school seniors. Journal of Youth and Adolescence, 35, 321-332.

Hughes, C., Blaxter, L., Brine, J., \& Jackson, S. (2006). Gender, class and 'race' in lifelong learning: policy and practice in the UK and EU. British Educational Research Journal, 32(5), 643-648.

Kauffman, D. F., \& Husman, J. (2004). Effects of time perspective on student motivation: Introduction to a special issue. Educational Psychology Review, 16, 1-7.

Kolesovs, A. (2013). Domain-specific and general future orientation of high school students in Latvia under socioeconomic changes. International Journal of Psychology: A Biopsychosocial Approach, 12, 71-83.

Nurmi, J.-E. (1991). How do adolescents see their future? A review of the development of 
future orientation and planning. Developmental Review, 11, 1-59.

Nurmi, J.-E. (2004). Socialization and self-development: Channeling, selection, adjustment, and reflection. In R. Lerner, \& L. Steinberg (Eds.), Handbook of adolescent psychology (pp. 85-124). New York, NY: Wiley.

Nurmi, J.-E., Poole, M., \& Seginer, R. (1995). Tracks and transitions - A comparison of adolescent future-oriented goals, explorations, and commitments in Australia, Israel, and Finland. International Journal of Psychology, 30, 355-375.

Pinquart, M., \& Silbereisen, R. K. (2004). Human development in times of social change: Theoretical considerations and research needs. International Journal of Behavioral Development, 28, 289-298.

Sandford, R. (2013). Located futures: Recognising place and belonging in narratives of the future. International Journal of Educational Research, 61, 116-125.

Seginer, R. (2009). Future orientation: Developmental and ecological perspectives. New York, NY: Springer.

Tabachnick, B. G., \& Fidell, L. S. (2007). Using Multivariate Statistics (5th ed.). Boston: Allyn and Bacon.

Vansteenkiste, M., Lens, W., \& Deci, E. L. (2006). Intrinsic versus extrinsic goal contents in self-determination theory: Another look at the quality of academic motivation. Educational Psychologist, 41, 19-31. 